Brit. J. industr. Med., 1964, 21, 283.

\title{
A BLOOD TEST DIAGNOSTIC OF EXPOSURE TO ALDRIN AND DIELDRIN
}

\author{
BY \\ V. K. H. BROWN, C. G. HUNTER, and A. RICHARDSON \\ From Shell Research Limited, Sittingbourne, Kent
}

(RECEIVED FOR PUBLICATION APRIL 22, 1964)

\begin{abstract}
The findings of a diagnostic blood test for the presence of hexachloro-epoxy-octahydrodimethanonaphthalene (H.E.O.D.) performed on whole blood obtained from operatives of plants manufacturing two chlorinated hydrocarbon insecticides, aldrin and dieldrin, and formulating products containing them and from dogs experimentally exposed to dieldrin have been reported. When clinical signs of poisoning were present, the concentration of H.E.O.D. in the blood was more than $16 \cdot 0-17.0 \mu \mathrm{g} . / 100 \mathrm{~g}$. blood. In the absence of clinical signs of intoxication the concentration of H.E.O.D. in the blood was less than these values. However, the concentration of H.E.O.D. found in several operatives and in two dogs who were without signs of intoxication was above these values. It is suggested that there is a concentration of H.E.O.D. in the blood of man and dog which is a threshold for intoxication. The value for the threshold concentration may be near $15 \cdot 0-20 \cdot 0 \mu \mathrm{g}$. $/ 100 \mathrm{~g}$. blood. An individual man or dog with a concentration of H.E.O.D. in the blood greater than the threshold is in a critical condition requiring some factor or factors not yet determined to precipitate intoxication. The use of this blood test will assess the severity of occupational exposure and support the diagnosis in suspected intoxication.
\end{abstract}

Ever since the chlorinated hydrocarbon insecticides have been used and handled, a blood test has been needed by industrial medical officers and physicians to assess and control exposures and to support the clinical diagnosis in suspected intoxication. Certainly a blood test of operatives in plants manufacturing these insecticides and formulating their products would obviate a biopsy of tissues (Kazantzis, McLaughlin, and Prior, 1964). Such a blood test has been developed recently from methods which determine the presence of small amounts of D.D.T.* and dieldrin (H.E.O.D.) $\dagger$ in tissues and biological fluids (Hunter, Robinson, and Richardson, 1963; Robinson, 1963). With this method the concentration of H.E.O.D. in the blood of 12 human males and females without occupational exposure, nine human males with occupational exposure, and one human female after an attempt at suicide has been reported (Robinson, 1963).

This paper presents the findings with this blood test using the same methods for measuring the

*2,2-bis(p-chlorophenyl)-1,1,1-trichlorethane.

†Dieldrin $85 \%$ H.E.O.D. : 1,2,3,4,10,10-hexachloro-6,-7-epoxy-1,4, 4a,5,6,7,8,8a-octahydro-endo-1,4-exo-5,8-dimethanonaphthalene. concentration of H.E.O.D. in the blood, in the case of blood obtained from (1) five male operatives of a plant who had formulated products containing aldrin $\neq$ two to five weeks previously and who had clinical signs of intoxication; (2) 20 healthy male laboratory staff with no history of occupational exposure, and 89 male operatives of another plant manufacturing aldrin and dieldrin and formulating products containing them; and (3) four pedigree dogs with signs of intoxication and two pedigree dogs without signs of intoxication during subacute oral exposure to dieldrin.

\section{Materials and Methods}

Samples of venous blood were taken by venoclysis from the operatives of the plants. Pedigree beagle dogs were exposed by repeated toxicity tests. Dieldrin ( $85 \%$ H.E.O.D.), 0.2 to $0.8 \mathrm{mg} . / \mathrm{kg}$. body weight, was administered by capsule daily to the fasting dog. On signs of intoxication a sample of

$\mp 1,2,3,4,10,10$-hexachloro- $1,4,4 \mathrm{a}, 5,8,8 \mathrm{a}$-hexahydro-endo- 1,4 - exo- 5 , 8-dimethanonaphthalene. Converted rapidly to H.E.O.D. in the issues of mammals (Kazantzis et al., 1964). 
blood was taken by venoclysis and the exposure was stopped. The dog was allowed to recover, a further sample of blood was taken by venoclysis, and another exposure was instituted.

The presence of H.E.O.D. in the blood was determined by the method of gas liquid chromatography with electron capture detection (Goodwin, Goulden, and Reynolds, 1961; Robinson, 1963) and the concentrations found were expressed in $\mu \mathrm{g} . / 100 \mathrm{~g}$. blood.

\section{Results}

The concentrations of H.E.O.D. found in the blood of five operatives of a plant formulating aldrin who had shown signs of chlorinated hydrocarbon insecticide intoxication (Kazantzis et al., 1964; Hayes, 1963) two to five weeks prior to venoclysis is tabulated in Table 1 . The concentration

TABLE 1

TIME AFTER INTOXICATION, CONCENTRATION OF H.E.O.D., FOUND AND PROBABLE (CALCULATED FROM BIOLOGICAL HALF-LIFE), IN THE BLOOD OF FIVE OPERATIVES

\begin{tabular}{c|c|c}
\hline $\begin{array}{c}\text { Time Since Exposure } \\
\text { and Intoxication } \\
\text { (weeks) }\end{array}$ & $\begin{array}{c}\text { Conc. of H.E.O.D. } \\
\text { Found } \\
(\mu \mathrm{g} . / 100 \mathrm{~g} .)\end{array}$ & $\begin{array}{c}\text { Probable Conc. of } \\
\text { H.E.O.D. during } \\
\text { Intoxication } \\
(\mu \mathrm{g} . / 100 \mathrm{~g} .)\end{array}$ \\
\hline $2 * *$ & $20 \cdot 0-25 \cdot 0$ & $22 \cdot 0-28 \cdot 0$ \\
3 & $36 \cdot 8$ & $43 \cdot 0$ \\
3 & $53 \cdot 0^{*}$ & 62.0 \\
4 & $13 \cdot 0$ & 16.0 \\
4 & 28.0 & 34.0 \\
5 & $13 \cdot 0$ & 17.0 \\
\hline
\end{tabular}

*Estimated from concentration of H.E.O.D. found in biopsy sample of body fat 60 p.p.m. and the measured blood/body fat ratio for $\operatorname{man}(1: 250 / 300)$.

* *Second intoxication 12 months after the first.

of H.E.O.D. was higher than $13.0 \mu \mathrm{g} . / 100 \mathrm{~g}$. When allowance is made for the lapse of time between the onset of symptoms (cessation of exposure) and the sampling of blood, the concentration of H.E.O.D. in the blood during intoxication was more than 16.0 to $17.0 \mu \mathrm{g} . / 100 \mathrm{~g}$. blood. These values are calculated from the known time for the concentration of H.E.O.D. in the blood of operatives on cessation of occupational exposure to fall to half the previous value. The biological half-life of H.E.O.D. in the blood of man is 97 days, with fiducial limits of 50 to 167 days (Robinson, J., personal communication).

The concentrations of H.E.O.D. in the blood of operatives without signs of intoxication are shown in Table 2. Less than $1 \mu \mathrm{g}$. $/ 100 \mathrm{~g}$. is found in the blood of healthy males without any history of exposure. The concentration of H.E.O.D. found in the blood of three groups of healthy operatives,
TABLE 2

OCCUPATION, EXPOSURE, AND CONCENTRATION OF H.E.O.D. FOUND IN THE BLOOD OF 20 NORMAL MALES AND 89 OPERATIVES MANUFACTURING AND FORMULATING ALDRIN AND DIELDRIN

\begin{tabular}{|c|c|c|c|c|}
\hline \multirow[t]{2}{*}{ Occupation } & \multirow[t]{2}{*}{ Exposure } & \multirow[t]{2}{*}{ No. } & \multicolumn{2}{|c|}{$\begin{array}{l}\text { Concentration of } \\
\text { H.E.O.D. in } \\
\text { Blood }(\mu \mathrm{g} . / 100 \mathrm{~g} .)\end{array}$} \\
\hline & & & Mean & Range \\
\hline $\begin{array}{l}\text { Laboratory staff } \\
\text { Refinery. }\end{array}$ & $\begin{array}{l}\text { Nil } \\
\text { Some years }\end{array}$ & $\begin{array}{l}20 \\
23\end{array}$ & $\begin{array}{l}0.25 \\
1.49\end{array}$ & $\begin{array}{l}0.05-1 \cdot 00 \\
0.20-5.00\end{array}$ \\
\hline $\begin{array}{l}\text { operatives } \\
\text { Refinery }\end{array}$ & $\begin{array}{c}\text { previously } \\
\text { Some months }\end{array}$ & 9 & 1.63 & $0 \cdot 40-3 \cdot 40$ \\
\hline $\begin{array}{l}\text { operatives } \\
\text { Formulation }\end{array}$ & $\begin{array}{l}\text { previously } \\
\text { Yes }\end{array}$ & 7 & 5.0 & $0.60-12 \cdot 00$ \\
\hline $\begin{array}{l}\text { operatives } \\
\text { Manufacturing } \\
\text { operatives }\end{array}$ & Yes & 50 & $7 \cdot 08$ & $0 \cdot 30-22 \cdot 00$ \\
\hline
\end{tabular}

those with a history of very slight exposure, those with a history of previous industrial exposure, and those working on manufacturing and formulating plants, is higher than in the healthy non-exposed male. The concentration, as would be expected, is highest in the operatives with most recent contact, the mean concentration being $7.08 \mu \mathrm{g}$. $/ 100 \mathrm{~g}$. In this group, the concentration in the blood of some operatives was in the range of those operatives of the formulation plant who had evinced overt intoxication (Table 1).

The concentration of H.E.O.D. in the blood of four dogs of both sexes during eight episodes of intoxication is shown in Table 3. The concentrations

TABLE 3

EXPOSURE AND CONCENTRATION OF H.E.O.D. IN THE BLOOD OF FOUR BEAGLE HOUNDS DURING EIGHT EPISODES OF INTOXICATION AND OF TWO HEALTHY BEAGLE HOUNDS WITHOUT INTOXICATION

\begin{tabular}{|c|c|c|c|c|}
\hline $\begin{array}{l}\text { No. of } \\
\text { Dogs }\end{array}$ & Sex & $\begin{array}{c}\text { Daily Oral } \\
\text { Exposure } \\
\text { (mg./kg. } \\
\text { body wt.) }\end{array}$ & $\begin{array}{l}\text { Episodes of } \\
\text { Intoxication } \\
\text { (no.) }\end{array}$ & $\begin{array}{c}\text { Concentration } \\
\text { of H.E.O.D. in } \\
\text { Blood } \\
(\mu \mathrm{g} . / 100 \text { g.) }\end{array}$ \\
\hline 4 & $\begin{array}{l}2 \mathrm{M} \\
2 \mathrm{~F}\end{array}$ & $0.4-0.8$ & 8 & $27 \cdot 0-127 \cdot 0$ \\
\hline 2 & $\begin{array}{l}1 \mathrm{M} \\
1 \mathrm{~F}\end{array}$ & 0.2 & None & $11 \cdot 0-22 \cdot 0$ \\
\hline
\end{tabular}

were in the range of 27.0 to $127.0 \mu \mathrm{g} . / 100 \mathrm{~g}$., the highest values being found in intoxications ending fatally. Likewise, the table shows the concentrations found in 16 examinations of the blood of two other healthy dogs on the lowest exposure and without signs of intoxication for eight months. In each analysis, the concentrations found were less than $22.0 \mu \mathrm{g} . / 100 \mathrm{~g}$. blood. Higher concentrations of H.E.O.D., 24.0 to $47.0 \mu \mathrm{g} . / 100 \mathrm{~g}$. blood, had been found in these dogs during a period of ill health and loss of weight believed to be unrelated to the exposure to dieldrin. The symptoms, pathologic 
physiology, and pathology of these dogs will be reported elsewhere.

In both operatives and dogs, the similarity of the concentrations of H.E.O.D. found in the blood during intoxication is an interesting observation. In the former, the values were above $16.0 \mu \mathrm{g} . / 100 \mathrm{~g}$. blood, and in the latter above $27.0 \mu \mathrm{g} . / 100 \mathrm{~g}$. blood.

\section{Discussion}

The symptomatology of intoxication by the chlorinated hydrocarbon insecticides is not specific, the symptoms and signs being those of excitation of the central nervous system. It was the history of exposure in factories manufacturing the insecticide and formulating products containing them and in the spraying campaigns in the field using these products that suggested to the physician that the sickness described in operatives and spraymen was caused by the absorption of the insecticide (Hayes, 1957; Hoogendam, Versteeg, and de Vlieger, 1962; and Kazantzis et al., 1964). Even an electroencephalogram, a helpful procedure in the control of industrial exposures and diagnosis of intoxication, is but a reflection of the excited state of the central nervous system (Hoogendam, Versteeg, and de Vlieger, 1964). Only a biological test for the presence or the effects of the presence of a poison in the tissues and body fluids of the exposed or clinically intoxicated will confirm the absorption of the toxicant. It is fortunate that a diagnostic blood test confirming the entry and giving an indication of the body burden of H.E.O.D. has been developed to protect operatives from intoxication and to support the clinical evidence of suspected intoxication. Further, the physician now has a most valuable aid in the differential diagnosis of sickness in those exposed occupationally or accidentally to products containing these materials, particularly if further information, both from laboratory experiments and occupational practice, confirms a relationship between intoxication and the concentration of H.E.O.D. in the blood.

We have described the results of analyses for the presence of H.E.O.D. in the blood obtained from operatives who showed signs of intoxication whilst formulating the chlorinated hydrocarbon insecticide, aldrin, and from healthy operatives of another plant manufacturing aldrin and dieldrin and formulating products containing them. These findings have been compared with the results of analyses of the blood of dogs orally exposed to dieldrin. The form and intensity of the exposures, the daily absorption of small amounts of the insecticide, are comparable, and since the clinical signs of intoxication in men and dogs do not differ unduly, there is good reason to accept that the findings in the experimental dog are applicable to man.

During occupational exposure to aldrin and dieldrin and products containing them, small quantities of these materials may be absorbed without evidence of ill health and intoxication, and in the healthy operatives of the second plant the concentration of H.E.O.D. in the blood was as high as $22.0 \mu \mathrm{g} . / 100 \mathrm{~g}$. (Table 2). However, if the exposure is intensified, as occurred in the first plant formulating aldrin, 12 hours daily, seven days weekly for three months (Kazantzis et al., 1964), then the over-exposure led to an increased absorption until one or more convulsive fits, repeated or not, and/or involuntary limb movements suggested to the physician overt intoxication. This type of intoxication, Hayes' Third Type (Hayes, 1963), was witnessed in the five operatives in whom the concentration of H.E.O.D. in the blood rose above $16.0 \mu \mathrm{g} . / 100 \mathrm{~g}$.

The relationship between the presence or absence of intoxication from the chlorinated hydrocarbon insecticides, aldrin and dieldrin, and the concentration of H.E.O.D. in the blood suggest that there may be a threshold concentration of H.E.O.D. in the blood for the overtness of intoxication. Should the concentration of H.E.O.D. in the blood exceed the threshold value, signs of intoxication may occur, but not necessarily so, since in both healthy operatives and in experimental dogs concentrations of H.E.O.D. in the blood have been found with values similar to those in intoxicated men and dogs. Where there are protracted exposures absorption may be slow, the concentration of H.E.O.D. gradually increasing until the threshold value is exceeded. When this occurs the individual man or dog is in a critical condition requiring a factor or factors, of which a sudden rise of blood level from increased absorption may well be one, to initiate the symptoms of intoxication. It seems that the threshold concentration of H.E.O.D. in the blood for intoxication may be in the range of 15.0 to $25.0 \mu \mathrm{g}$. $/ 100 \mathrm{~g}$. blood.

The mechanism of intoxication from the chlorinated hydrocarbon insecticides, aldrin and dieldrin, remains unknown. As mentioned already, one factor in the intoxication, the rate of absorption, must be of importance. Over a period of months, the experimental rodent may accumulate in its depot fat amounts of chlorinated hydrocarbon insecticides which are larger than single oral lethal exposures (Hayes, 1963). Man also may accumulate quite large quantities, 149 p.p.m., of H.E.O.D. in depot fat without an illness severe enough to 
demand medical care, provided the rate of absorption is slow (Kazantzis et al., 1964). But if the absorption of the chlorinated hydrocarbon insecticide is increased, as in an occupational overexposure or in higher experimental exposures, to 0.4 to $0.8 \mathrm{mg}$. dieldrin $/ \mathrm{kg}$. body weight daily, the concentration of H.E.O.D. in the blood exceeds the threshold and a critical situation exists. It may then require only the initiating factors of a further rapid absorption, an intercurrent illness, or an environmental stress to produce intoxication.

A hypothesis that there is a concentration in the blood for intoxication which if exceeded promotes a critical situation for lead poisoning has been accepted in the case of the metabolism of lead (Kehoe, 1961). The threshold concentration is $80 \mu \mathrm{g}$. lead $/ 100 \mathrm{~g}$. blood. In individuals whose concentrations of lead in the blood are below this figure 'no case even of the mildest type of poisoning' has been found. On the other hand, concentrations of lead in the blood above this figure have been found in healthy operatives. However, they are in a critical condition requiring but the over-burdening of tissues with unbound lead from a sudden rapid absorption of lead or a release of biochemical bonds to develop lead intoxication. The pathogenesis of intoxication from the chlorinated hydrocarbon insecticides may be very similar.

The limited information at present available suggests that the threshold concentration of H.E.O.D. in the blood of man critical for intoxication may be $15.0 \mu \mathrm{g} . / 100 \mathrm{~g}$. Certainly, if concentrations in the blood of operatives manufacturing aldrin or dieldrin or formulating their products are found to be greater than this figure, the exposure should cease, medical supervision should be instituted, and the environmental hygiene should be investigated. If intoxication is suspected from exposure to aldrin and dieldrin a blood test should be made immediately. The result may or may not support the clinical findings, but on present evidence the diagnosis of intoxication may not be supported unless the concentration of H.E.O.D. in the blood exceeds the threshold value proposed in this paper. Nevertheless, the diagnosis of intoxication rests on the history of exposure and the clinical symptomatology, since illnesses arising from causes other than chlorinated hydrocarbon insecticide intoxication are possible even in those whose concentration of H.E.O.D. in the blood is raised above the suggested threshold.

Further experiment and experience with cases of human over-exposure may qualify the present limited findings, but a diagnostic blood test is available for the clinical and industrial physician dealing with exposure, occupational or accidental, to the chlorinated hydrocarbon insecticides, aldrin and dieldrin.

We are most grateful to Dr. G. Kazantzis of the M.R.C. Unit, St. Bartholomew's Hospital, and to Dr. I. Hoogendam, Shell Pernis Raffinaderij N.V., Rotterdam, for forwarding the samples of blood of the exposed operatives.

\section{REFERENCES}

Goodwin, E. S., Goulden, R., and Reynolds, J. G. (1961). Analyst,

Hayes, W6, J. (1957). Publ. Hlth Rep. (Wash.), 72, 1087.

(1963). Clinical Handbook of Economic Poisons, p. 14. U.S. Dept of Health, Education \& Welfare, Atlanta, Georgia.

Hoogendam, I., Versteeg, J. P. J., and de Vlieger, M. (1962). ${ }^{\text {Arch. }}$ environm. Hlth, 4, 86

$\overline{\text { Hunter, C}}, \overline{G .,}$ Robinson, J., and Richardson, A. (1963). Brit. med. $J ., 1,221$.

Kazantzis, G., McLaughlin, A. I. G., and Prior, P. F. (1964). Brit. J. industr. Med., $21,46$.

Kehoe, R. A. (1961). J. roy. Inst. publ. Hlth, 24, 177.

Robinson, J. (1963). Proc. 3rd Int. Meeting in Forensic Immunology, Medicine, Pathology and Toxicology, London, in the press. 